\title{
DIGITALISASI EKONOMI SYARIAH
}

\section{Aan Ansori}

IAIN Sultan Maulana Hasanuddin Banten

\begin{abstract}
Abstrak. Digitalisasi Ekonomi Syariah. Digitalisasi ekonomi syariah dapat merambah dalam berbagai aspek ekonomi baik ekonomi mikro maupun ekonomi makro. Sekarang ini peran digital sangat luar biasa, hampir semua perekonomian menggunakan teknologi informasi dan komunikasi atau digitalisasi, baik dalam mengemas produk ataupun dalam memasarkan produk, sehingga lebih mudah dan lebih cepat dalam distribusi informasi yang digunakan untuk membuat pertumbuhan ekonomi semakin cepat dan tiada batas dengan dukungan teknologi digital dan teknologi informasi. Teknologi informasi yang sudah merambah keindividu (personal) dapat mendukung era digitalisasi informasi dan komunikasi pada ekonomi konvensional maupun ekonomi syariah, teknologi tersebut sekarang sudah dalam genggaman tangan pengguna gadget seperti aplikasi mobile yang dapat diunduh dan dipasang dengan fitur mudah dimengerti oleh user. Demikian pula di dunia perbankan, dalam melakukan kegiatannya perbankan syariah bekerja sama dengan bidang teknologi informasi untuk membangun sistem informasi perbankan syariah dengan membuat aplikasi khusus (app) yang dapat mempermudah semua proses-proses transaksi yang ada diperbankan. Terbentuknya masyarakat digital akibat dari tersebut dipacu oleh perkembangan dan penerapan teknologi informasi dan komunikasi yang sangat intensif di semua bidang baik ekonomi, pemasaran, keuangan, jasa, pendidikan dan sebagainya. Maka, digitalisasi terbentuk untuk memudahkan pengguna dalam melakukan transaksi, sehingga perekonomian meningkat.
\end{abstract}

Kata Kunci: Digitalisasi, Syariah.

Abstract. Digitalization of Islamic Economics. Digitizing sharia economy can be expanded in various economic aspects of both microeconomics and macroeconomics. Now, the role of digital is very unusual, almost all economies using information and communication technologies or digitalisation, both in packaging products or in marketing the product, making it easier and quicker distribution of information used to make economic growth more quickly and there is no limit to the support digital technology and information technology. Information technology has penetrated keindividu (personal) can support the digitization era of information and communication in the conventional economy and sharia economy, the technology is now in the palm of your hand gadgets such as mobile applications that can be downloaded and installed with features easily understood by the user. Similarly, in the world of banking, Islamic banking in conducting its activities in cooperation with information technology to establish Islamic banking information system by creating a special application (app) that can simplify all the processes of ownership in the existing transaction. Establishment of the digital society as a result of the accelerated by the development and application of information and communication technology is very 
Aan Anshori:Digitalisasi Ekonomi Syariah

intensive in all fields of economy, marketing, finance, services, education and so forth. Thus, digitization is formed to allow users in the transaction, so that the economy increased.

Keywords: Digitalization, Syariah.

\section{Latar Belakang}

Teknologi Digital merupakan peralihan dari pengoperasionalannya tidak lagi banyak menggunakan tenaga manusia. tetapi lebih cenderung pada sistem pengoprasian yang serba otomatis dan canggih dengan system computer, dalam bentuk bilangan biner (nol dan satu) dengan format yang dapat dibaca oleh komputer. Teknologi digital pada dasarnya hanyalah sistem menghitung sangat cepat yang memproses semua bentuk-bentuk informasi sebagai nilai-nilai numeris. Pada teknologi analog, gambar dan suara diubah menjadi gelombang radio, maka teknologi digital menkonversi gambar dan suara menjadi data digital yang terdiri dari angka 1 dan 0. Dengan teknologi digital ini, gambar yang ditampilkan memiliki kualitas warna yang lebih natural dan resolusi yang lebih baik, tidak pecah atau turun kualitasnya jika gambar ditampilkan di layar yang besar.

Pesatnya perkembangan teknologi digital yang ditandai dengan kehadiran sejumlah berbagai alat komunikasi mutakhir, dimana setiap orang dapat mengolah, memproduksi, serta mengirimkan maupun menerima segala bentuk pesan komunikasi, di mana saja dan kapan saja, seolah-olah tanpa mengenal batasan ruang dan waktu, dengan sendirinya telah memacu terjadinya perkembangan di sektor media massa, yang merupakan bagian dari komponen komunikasi. Akibatnya, serbuan informasi yang bersumber dari media massa, baik cetak maupun elektronik mulai terasa. Disadari atau tidak, saat ini kita memang telah berada dalam suatu lingkaran yang sarat akan informasi. Hal ini tentunya akan memberikan dampakdampak tertentu bagi masyarakat, baik positif maupun negatif. Namun pastinya, yang perlu diwaspadai adalah dampak negatif dari pesatnya perkembangan tersebut yang secara tidak langsung mulai mengisi liku-liku kehidupan masyarakat. Sebagai catatan, dalam beberapa dasawarsa terakhir ini perkembangan media massa dan arus informasi di Indonesia memang terbilang luar biasa.

Untuk dapat bertahan dan memenangkan persaingan dalam ekonomi digital, para pemain perlu memahami karakteristik dari konsep yang menjadi landasan 
Islamiconomic: Jurnal Ekonomi Keuangan dan Bisnis Islam Vol.7 No.1 Januari - Juni 2016

karena sangat berbeda dengan ekonomi klasik yang selama ini dikenal. Tidak jarang bahwa perusahaan harus melakukan transformasi bisnis agar dapat secara optimal bermain di dalam arena ekonomi digital. Hal ini disebabkan karena untuk mengimplementasikannya, diperlukan model bisnis yang sama sekali baru. Bagi perusahaan baru (start-up company), untuk terjun ke bisnis ini biasanya lebih mudah dibandingkan dengan perusahaan yang telah lama berdiri. Statistik menunjukkan bahwa sebagian besar perusahaan lama yang ingin memanfaatkan keberadaan ekonomi digital harus mengadakan perubahan mendasar pada proses bisnisnya secara radikal (business process reengineering).

Ekonomi syariah sebagai suatu pemikiran ekonomi yang dianggap dapat menjadi alternatif dari pemikiran ekonomi saat ini sedang berkembang pesat di seluruh dunia dalam 10 tahun terakhir.Suatu pemikiran yang pada awal kehadirannya merupakan suatu kemustahilan, namun pada saat ini sudah merambah banyak negara di dunia.Negara-negara tersebut pun tidak semuanya negara dengan mayoritas penduduknya muslim, tetapi juga negara dengan mayoritas penduduk nonmuslim. Contohnya adalah perkembangan pesat keuangan syariah di Inggris yang kemudian mencoba menjadi pusat keuangan syariah di dunia.Di tengah perkembangan yang amat pesat dan kondisi kita saat ini yang sedang berada di era digital dapat membuat ekonomi syariah semakin menyebarkan pengaruhnya ke seluruh penjuru dunia.Ekonomi syariah dengan segala infrastruktur dan instrumennya harus mampu mengambil peluang yang sangat besar ini. Kesempatan emas ini harus dimanfaatkan dengan sebaik-baiknya oleh para penggiat ekonomi syariah.Banyak hal yang dilakukan dalam dunia digital seperti sekarang ini dalam mengembangkan ekonomi syariah, khususnya di Indonesia. Indonesia yang memiliki gelar negara dengan penduduk muslim terbesar di dunia ini memiliki potensi sangat besar dalam pengembangan ekonomi syariah.

Berdasarkan sensus Badan Pusat Statistik, jumlah penduduk muslim di Indonesia berada di kisaran 87\% atau sekitar 207 juta jiwa. Jumlah yang sangat besar ini harus dimanfaatkan dengan sangat jeli, terlebih ketika kita dapat dengan mudah mengakses teknologi smartphone sebagai dampak kemajuan teknologi digital. ${ }^{1}$ 


\section{Rumusan Masalah}

Berdasarkan uraian latar belakang fenomena yang ada mengenai digitialisasi ekonomi syari'ah pada sub bab diatas, maka peneliti membuat suatu perumusan masalah yang dapat disajikan dalam pertanyaan:

1) Mengapa diperlukan sekali digitialisasi ekonomi syari'ah pada era globalisasi teknologi gadget?

2) Bagaimana pemanfaatan digitialisasi ekonomi syari'ah?

3) Bagaimana tingkat kepercayaan pengguna terhadap digitialisasi ekonomi syari'ah?

\section{Tujuan Penelitian}

Secara spesifik penelitian ini dilakukan dengan tujuan untuk mengetahui secara mendalam alasan mengapa digitialisasi ekonomi syari'ah diperlukan dalam membangun perekonomian pada era globalisasi dengan teknologi informasi yang sangat berkembang cepat sehingga dunia pada genggaman, dengan gadget semua bisa dilakuakn tanpa ada batasan ruang dan waktu.

\section{Landasan Teori}

Pengertian Ekonomi Syariah atau Pengertian Ekonomi Islam menurut M.A. Manan adalah ilmu pengetahuan sosial yang mempelajari masalah-masalah ekonomi rakyat yang diilhami oleh nilai-nilai islam.

Menurut Muhammad Abdullah abdullah al-'Arabi, Pengertian Ekonomi Syariah atau Pengertian Ekonomi Islam ialah sekumpulan dasar-dasar umum ekonomi yang kita simpulkan dari alquran dan sunnah, dimana merupakan bangunan perekonomian yang didirikan di atas landasan dasar-dasar tersebut sesuai tiap lingkungan dan masa.

Menurut Prof. Dr. Zainuddin Ali, Pengertian Ekonomi Syariah atau Pengertian Ekonomi Islam adalah kumpulan norma hukum yang bersumber dari alquran dan hadist yang mengatur perekonomian umat manusia.

Menurut Dr. Mardani, Pengertian Ekonomi Syariah atau Pengertian Ekonomi Islam yaitu usaha atau kegiatan yang dilakukan oleh orang per orang atau kelompok orang atau badan usaha yang berbadan hukum atau tidak berbadan hukum dalam 
Islamiconomic: Jurnal Ekonomi Keuangan dan Bisnis Islam

Vol.7 No.1 Januari - Juni 2016

rangka memenuhi kebutuhan yang bersifat komersial dan tidak komersial menurut prinsip syariah.

Dari pengertian ekonomi syariah diatas, dapat disimpulkan bahwa Pengertian Ekonomi Syariah atau Pengertian Ekonomi Islam adalah sistem ekonomi yang bersumber dari wahyu yang transendental (alquran dan hadist) dan sumber interpretasi dari wahyu yang disebut dengan ijtihad. ${ }^{2}$

Pada dasarnya ilmu ekonomi adalah ilmu yang menjelaskan cara untuk memenuhi kebutuhan hidup manusia, guna menjaga kelangsungan hidupnya. Maka,tidak ayalnya dengan ekonomi lainnya bahwa ekonomi syariah merupakan ilmu yang dapat diterapkan dalam sendi-sendi kehidupan manusia dalam pemenuhan kelangsungan hidupnya.

Sistem ekonomi pertama di muka bumi adalah ekonomi islam. Terbukti di zaman Rosulullah S.A.W pada saat itu Nabi Muhammad mengajari para sahabatnya bagaimana berdagang yang benar, jujur, dan adil.

Dan Rosul juga mengajarkan kepada umatnya untuk menyisihkan 2,5\% dari hartanya untuk di sedekahkan kepada orang orang yang membutuhkan atau mustahiq. Hal ini bertujuan agar tidak ada kesenjangan antara si miskin dan si kaya. Si kaya memberikan sedikit harta nya untuk orang miskin. Dengan demikian sudah terbukti bahwa ekonomi islam sudah ada pada zaman Rosulullah, akan tetapi seiring berkembangnya zaman muncul madzab-madzah baru yang menganut ekonomi liberalisme, komando atau sosialisme dan kapitalisme.

Mereka hanya mengambil sebagian dari perinsip ekonomi islam. Mana yang bagi mereka bisa diterima akal dia ambil, jika tidak maka mereka menolaknya. ${ }^{3}$

Sistem ekonomi islam adalah sistem ekonomi yang dijalankan berdasarkan syariat islam atau aturan-aturan Allah. Sistem ini bertitik tolak dari Allah, bertujuan akhir pada Allah, dan menggunakan sarana yang tidak lepas dari syariat islam

Dalam segala kegiatan ekonomi yang dilakukan manusia harus sesuai dengan ketentuan Allah baik dalam hal jual beli, simpan pinjam, investasi. Dalam islam konsep kepemilikan harta adalah harta sepenuhnya adalah milik Allah sementara manusia sebagai khalifah atas harta tersebut. Selain itu juga islam sangat melarang manusia melakukan tindakan Maisyir, Gharar, Haram, Dzalim, ikhtikar, Riba. 
Prinsip ekonomi islam dalam membangun perekonomian umat adalah dengan berpatokan pada rambu-rambu yang telah ditetapkan sebagai berikut:

a) Larangan Maisyir. Maisyir adalah suatu tindakan perjudian yang berarti seseorang ingin mendapatkan harta tanpa harus bersusah payah bekerja juga suatu tindakan memperkaya diri dengan cara merugikan orang lain

b) Larangan Gharar. Gharar yaitu suatu tindakan penipuan yang dapat merugikan orang lain, dimana dalam transaksi terdapat unsur- unsur tersembunyi yang dilakukan oleh salah satu pihak untuk mendapatkan keuntungan. Gharar berakibat sangat buruk yaitu akan menimbulkan kebencian pada pihak yang bertransaksi.

c) Larangan melakukan hal Haram. Yaitu hukum yang dijatuhkan pada suatu dzat atau benda yang dilarang untuk digunakan atau dikonsumsi karena dilarang oleh Allah baik dari barang itu sendiri maupun cara memperolehnya.

d) Larangan Dzalim. Yaitu tindakan yang merugikan orang lain maupun menyakiti orang lain untuk maksud tertentu, karena dalam islam ekonomi yang dilakukan harus atas dasar saling ridho maka islam tidak membenarkan hal ini.

e) Larangan Ikhtikar. Yaitu suatu kegiatan penimbunan barang untuk maksud memperoleh keuntungan yang besar dengan cara menahan suatu barang dalam suatu keadaan dan akan memjualnya kembali pada saat harga sedang melonjak.

f) Larangan Riba. Yaitu tambahan atas suatu transaksi yang dilakukan biasanya dalam utang piutang yaitu dalam bentuk bunga. Islam tidak membenarkan riba dalam bentuk apapun walaupun keduanya sama-sama rela, kecuali dalam bentuk bonus atau bentuk terima kasih peminjam kepada yang meminjamkannya. ${ }^{4}$

Definisi Digital Economy versi Encarta Dictionary adalah "Business transactions on the Internet: the marketplace that exists on the Internet". Pengertian Digital Economy lebih menitikberatkan pada transaksi dan pasar yang terjadi di dunia internet. Pengertian yang lebih luas dari sekedar transaksi atau pasar adalah New Economy yang menurut PC Magazine adalah "The impact of information technology on the economy". Pengertiannya lebih menonjolkan pada penerapan teknologi informasi pada bidang ekonomi.Bisa dimengerti karena PC Magazine adalah majalah khusus tentang dunia IT Majalah The Economist menyebutkan bahwa isitilah New Economy 6 
Islamiconomic: Jurnal Ekonomi Keuangan dan Bisnis Islam Vol.7 No.1 Januari - Juni 2016

lahir karena keberadaan IT dan globalisasi yang menyebabkan terjadinya tingkat produktifitas dan pertumbuhan (perusahaan atau negara) sangat tinggi. Istilah $\mathrm{New}$ Economy memang pertama kali muncul di Amerika Serikat. Menurut studi Kauffman dan ITIF, New Economy diukur dengan sejumlah indikator yang dikelompokkan dalam lima komponen yaitu pekerjaan berbasis pengetahuan, globalisasi, dinamisme ekonomi, transformasi ke digital economy, dan kapasitas inovasi teknologis.

Mengacu ke beberapa definisi dan indikator pengukuran New Economy, sudah dapat diduga bahwa Indonesia masih belum mencapai atau mengandalkan New Economy dalam perkembangan perekonomian nasional. Sedikit gambaran mengenai laju penerapan ICT di Indonesia dan posisinya di tingkat international dapat dilihat di tulisan "Dowloader Society". Indikasinya adalah masih rendahnya penetrasi ICT- atau sering disebut ICT Density. Perbedaaan ICT density antar kelompok tersebut disebut dengan kesenjangan digital atau Digital Divide. Pengertian kelompok bisa ditinjau antar negara (misalnya negara maju vs negara berkembang), antar demografi individual (pria vs wanita, pendidikan tinggi vs rendah, antar profesi), antar geografis (Kota vs Desa, Jawa vs Luar Jawa), atau antar tipe bisnis (antar sektor usaha, industri besar vs kecil).

Perkembangan dan kemajuan teknologi informasi dan komunikasi (TIK) akhirakhir ini dirasakan hampir di setiap aspek kehidupan masyarakat. Sebagaimana setiap kemajuan teknologi komunikasi yang lain, internet masuk ke berbagai bentuk kehidupan masyarakat. Hal ini terjadi karena komunikasi adalah salah satu kebutuhan yang mendasar pada masyarakat. Teknologi internet berkembang dan menyatu dalam sebuah 'dunia' atau 'ruang maya' atau sering disebut sebagai cyberspace, sebuah dunia atau tempat orang dapat berkomunikasi, 'bertemu', dan melakukan berbagai aktivitas ekonomi/bisnis.

Dampak evolusi itu di masyarakat mendorong munculnya masyarakat baru yang dinamakan masyarakat informasi (information society) atau masyarakat berpengetahuan (knowledge society/knowledge-based society). Pada mulanya, teori ekonomi fundamental lama berlandaskan pada optimalisasi/maksimalisasi faktorfaktor produksi yaitu: fisik, tenaga kerja, kapital (tanah, modal uang, dan manusia). Pada perkembangannya sekarang ilmu ekonomi menyadari pentingnya memasukkan faktor-faktor intelektualitas berupa ilmu pengetahuan dan teknologi, kreativitas, dan 
Aan Anshori:Digitalisasi Ekonomi Syariah

berbagai bentuk modal inovatif yang dapat dikategorisasikan sebagai iptek (ilmu pengetahuan dan teknologi).

Berbagai perkembangan inovasi pada teknologi informasi dan telekomunikasi (TIK) atau teknologi digital selama satu dekade terakhir, berdampak pada bidang ekonomi dan bisnis disebut sebagai masyarakat pascaindustri (post industrial society), ekonomi berlandaskan iptek, ekonomi inovasi, ekonomi online, ekonomi baru, e-conomy, dan ekonomi digital. (Cohen et al., 2000). Ekonomi digital adalah suatu hal yang kompleks dan merupakan fenomena yang baru muncul terkait dengan aspek-aspek ekonomi mikro, ekonomi makro, dan teori organisasi dan administrasi. Ekonomi digital akan menjelaskan perkembangan dan pertumbuhan ekonomi beberapa dekade yang akan datang.

Konsep mengenai digital ekonomi pertama kali diperkenalkan Tapscott (1998), menjelaskan sebuah sosiopolitik dan sistem ekonomi yang mempunyai karakteristik sebagai sebuah ruang intelijen, meliputi informasi, berbagai akses instrumen informasi dan pemrosesan informasi dan kapasitas komunikasi. Komponen ekonomi digital yang berhasil diidentifikasi pertama kalinya adalah industri TIK, aktivitas ecommerce antarperusahaan dan individu, distribusi digital barang-barang dan jasajasa, dukungan pada penjualan-penjualan barang-barang terutama sistem dan jasajasa yang menggunakan internet.

Sedangkan konsep ekonomi digital lainnya adalah digitalisasi informasi dan infrastruktur TIK (Zimmerman, 2000). Konsep ini sering digunakan untuk menjelaskan dampak global teknologi informasi dan komunikasi, tidak hanya pada internet, tetapi juga pada bidang ekonomi. Konsep ini menjadi sebuah pandangan tentang interaksi antara perkembangan inovasi dan kemajuan teknologi dan dampaknya pada ekonomi makro maupun ekonomi mikro. Ekonomi digital adalah sektor ekonomi meliputi barang-barang dan jasa-jasa saat pengembangan, produksi, penjualan atau suplainya tergantung kepada teknologi digital.

Sebuah perkembangan ekonomi digital tidak lepas dari karakteristik/sifatnya yakni adanya penciptaan nilai, produk berupa efisiensi saluran distribusi, dan struktur berupa terjadinya layanan personal dan sesuai keinginan. Di Indonesia, sistem Bank Indonesia real time gross settlement (RTGS) yakni suatu sistem transfer elektronik antarpeserta dalam mata uang rupiah yang penyelesaiannya dilakukan 
Islamiconomic: Jurnal Ekonomi Keuangan dan Bisnis Islam Vol.7 No.1 Januari - Juni 2016

secara seketika (real time), per transaksi secara individual, jumlahnya cukup signifikan banyaknya, yakni bergerak antara Rp3 triliun sampai Rp4 triliun per bulan. Hal tersebut dapat dikategorikan sebagai sebuah transaksi e-banking yang menjadi bagian dari pada ekonomi digital. Demikian pula dengan transaksi belanja e-banking untuk kartu ATM dan kartu debit.

Dari segi sosial dan budaya, masyarakat Indonesia pada saat ini sudah semakin maju. Terbukti menurut survey dari situs WorlBank.org, Indonesia mengalami peningkatan pengguna internet yang cukup signifikan. Hal ini menunjukkan bahwa penduduk Indonesia mulai mengikuti perkembangan teknologi di dunia. Hal ini juga menjadi parameter pertumbuhan perekonomian digital suatu negara.

Dari segi lingkungan hukum, dalam menjaga kestabilan dan keamanan teknologi informasi dan komunikaasi, terutama internet di Indonesia. Departemen Komunikasi dan Informatika Republik Indonesia membentuk Indonesia Security Incident Response Team on Internet and Infrastructure (ID-SIRTII) yang bertujuan untuk mengimbangi dengan kesiapan infrastruktur strategis untuk meminimalisir dampak negatif dari jaringan internet di Indonesia. Yang bertugas melakukan sosialisasi dengan pihak terkait tentang keamanan sistem informasi, melakukan pemantauan, pendeteksian, peringatan dini terhadap ancaman terhadap jaringan telekomunikasi dari dalam maupun luar negeri khususnya dalam pengamanan pemanfaatan jaringan, membuat/menjalankan/mengembangkan serta statistik keamanan internet di Indonesia. ${ }^{5}$

\section{Digitalisasi Ekonomi Syariah}

Dalam perekonomian syari'ah yang terdigitalisasi memungkinkan semua dalam bentuk dunia maya atau yang sering disebut dengan bisnis dunia maya seperti; $e$ commerce, e-business, e-banking, e-payment, e-marketing, e-learning dan lain sebagainya, meliputi berbagai aspek sebagai berikut:

\section{Knowledge}

Pengetahuan dari sumber daya manusia (knowlagde) merupakan hal terpenting dalam kelangsungan suatu perusahaan atau instansi dan merupakan aset dari perusahaan atau instansi, pada teori ekonomi sebelumya yaitu ekonomi klasik yang merupakan aset bagi perusahaan atau instansi 
adalah tanah, gedung, buruh, dan uang. Mengingat pentingnya bahwa pengetahuan melekat pada otak manusia, maka faktor intelegensia dari sumber daya manusia yang dimiliki perusahaan merupakan penentu sukses tidaknya organisasi tersebut dalam mencapai obyektifnya. Pengetahuan kolektif inilah yang merupakan value dari perusahaan dalam proses penciptaan produk dan jasa. Di samping itu, kemjuan teknologi telah mampu menciptakan berbagai produk kecerdasan buatan (artificial intelligence) yang pada dasarnya mampu membantu manajemen dan pegawai perusahaan atau instansi untuk meningkatkan kemampuan intelegensianya (knowledge leveraging). Sebagai contoh produk perangkat lunak (software) dan perangkat keras (hardware) yang dapat menjadi sistem penunjang pengambilan keputusan adalah decision support system dan expert system. Konsep knowledge management akan menjadi kunci keberhasilan sebuah perusahaan di era ini.Sumber: Don Tapscott et al, 1996.

\section{Digitization}

Digitazition merupakan suatu proses transformasi informasi dari berbagai bentuk menjadi format digit "0" dan " 1 " (bilangan biner). Walaupun konsep tersebut sekilas nampak sederhana, namun keberadaannya telah menghasilkan suatu terobosan dan dampak perubahan yang sangat besar di dalam dunia transaksi bisnis yang di tranformasikan dalam bentuk digital sehingga memudahkan penyimpanan yang efektif dan efesien dalam bentuk yang lebih padat dan sekarang ini bahkan untuk menampung data cukup dengan icloud saja. Lihatlah bagaimana bentuk gambar dua dimensi seperti lukisan dan foto telah dapat direpresentasikan ke dalam format kumpulan bit sehingga dapat dengan mudah disimpan dan dipertukarkan melalui media elektronik. Hal ini tentu saja telah dapat meningkatkan efisiensi perusahaan karena mengurangi biaya-biaya terkait dengan proses pembuatan, penyimpanan, dan pertukaran media tersebut. Bahkan teknologi terakhir telah dapat melakukan konversi format analog video dan audio ke dalam format digital. Kemajuan teknologi telekomunikasi yang memungkinkan manusia untuk saling bertukar informasi secara cepat melalui email ke seluruh penjuru 
Islamiconomic: Jurnal Ekonomi Keuangan dan Bisnis Islam Vol.7 No.1 Januari - Juni 2016

dunia semakin memudahkan proses pengiriman dan pertukaran seluruh jenis informasi yang dapat di-digitasi. Dengan kata lain, jika produk dan jasa yang ditawarkan dapat direpresentasikan dalam bentuk digital, maka perusahaan dapat dengan mudah dan murah menawarkan produk dan jasanya ke seluruh dunia. Electronic publishing, virtual book store, internet banking, telemedicinedan icloudmerupakan contoh berbagai produk dan jasa yang dapat ditawarkan oleh dunia digital.

\section{Virtualization}

virtualiasasi yang memungkinkan seseorang untuk memulai bisnisnya dengan perangkat sederhana (perangkat PC dengan koneksi data internet) dan dapat menjangkau seluruh calon pelanggan di dunia maya (internet), sudah dapat melakukan transaksi bisnisnya.Berbeda dengan menjalankan bisnis di dunia nyata dimana membutuhkan aset-aset fisik semacam gedung dan alat-alat produksi untuk melakakan transaksi bisnisnya. Di dalam dunia maya, seorang pelanggan hanya berhadapan dengan sebuah situs internet sebagai sebuah perusahaan (business to consumer), demikian pula relasi antara berbagai perusahaan yang ingin saling bekerja sama (business to business). Dalam menjalin hubungan ini, proses yang terjadi lebih pada transaksi adalah pertukaran data dan informasi secara virtual, tanpa kehadiran fisik antara pihak-pihak atau individu yang melakukan transaksi. Dengan kata lain, bisnis dapat dilakukan kapan saja dan dimana saja selama 24 jam per-hari dan 7 hari seminggu secara on-line dan real time dengan syarat terkoneksi jaringan internet.

\section{Molecularization}

Organisasi yang akan bertahan dalam era ekonomi digital adalah yang berhasil menerapkan bentuk molekul. Bentuk molekul merupakan suatu sistem dimana organisasi dapat dengan mudah beradaptasi dengan setiap perubahan dinamis yang terjadi di lingkungan sekitar perusahaan. Seperti diketahui, pada masa ini mayoritas organisasi dikelola dengan menggunakan konsep struktur hirarkis atau yang lebih maju lagi struktur matriks. Kedua konsep ini sangat 
rentan terhadap perubahan sehingga akan memperlambat gerak perusahaan dalam menyesuaikan diri dengan perkembangan pasar. Satu hal yang harus diingat adalah bahwa terjun ke dunia maya (internet) berarti berhadapan head-to-head dengan perusahaan-perusahaan di seluruh dunia. Perilaku mereka setiap hari akan sangat mempengaruhi struktur pasar dan industri terkait yang seringkali akan merubah berbagai kondisi. Hal ini tentu saja merupakan manifestasi dari persaingan bebas dan ketat yang terjadi disamping merupakan strategi untuk memenangkan rivalitas. Dengan kata lain, perubahan merupakan proses wajar yang harus dilakukan oleh perusahaan. Charles Darwin mengatakan bahwa bangsa yang akan bertahan bukanlah yang paling besar atau paling kuat, melainkan yang paling mampu beradaptasi dengan perubahan.

\section{Internetworking}

Internetworkingmerupakan hal terpenting dalam melakukan transaksi bisnis baik secara elektronik maupun secara konvensional dengan ketemu muka dan melakukan transaksi bisnis, tidak ada perusahaan yang dapat bekerja sendiri tanpa menjalin kerja sama dengan pihak-pihak lain, demikian salah satu perasyarat untuk dapat berhasil di dunia maya. Berdasarkan model bisnis yang dipilih, perusahaan terkait harus menentukan aktivitas inti-nya (core activity) dan menjalin kerja sama dengan institusi lain untuk membantu melaksanakan proses-proses penunjang (supporting activities). Contoh dari pihak-pihak yang umum dijadikan sebagai rekanan adalah vendor teknologi, content partners, merchants, pemasok (supplier), dan lain sebagainya. Konsep bisnis yang ingin menguasai sumber daya sendiri dari hulu ke hilir tidak akan bertahan lama di dalam ekonomi digital. Dengan sistem yang dinamis dan membuka peluang sebesar-besarnya dalam hal ini siapapun dapat ikut besaing dan juga tidak dibatasi oleh ruang dan waktu selama terkoneksi oleh jaringan komunikasi internet.

\section{Disintermediation}

Ciri khas lain dari arena ekonomi digital adalah kecenderungan berkurangnya 
Islamiconomic: Jurnal Ekonomi Keuangan dan Bisnis Islam Vol.7 No.1 Januari - Juni 2016

mediator (broker) sebagai perantara terjadinya transaksi antara pemasok dan pelanggan. Contohnya mediator-mediator dalam aktivitas ekonomi adalah wholesalers, retailers, broadcasters, record companies, dan lain sebagainya. Perusahaan-perusahaan klasik yang menggantungkan diri sebagai mediator dengan sendirinya terpaksa harus gulung tikar dengan adanya bisnis internet. Pasar bebas memungkinkan terjadinya transaksi antar individu tanpa harus melibatkan pihak-pihak lain.

\section{Convergence}

Kunci sukses perusahaan dalam bisnis internet terletak pada tingkat kemampuan dan kualitas perusahaan dalam mengkonvergensikan tiga sektor industri, yaitu: computing, communications, dan content. Komputer yang merupakan inti dari industri computing merupakan pusat syaraf pengolahan data dan informasi yang dibutuhkan dalam melakukan transaksi usaha. Adapun produk industri communications yang paling relevan adalah infrastruktur teknologi informasi dan komunikasi sebagai pipa penyaluran data dan informasi dari satu tempat ke tempat lainnya. Persaingan sesungguhnya terletak pada industri content yang merupakan jenis pelayanan atau jasa yang ditawarkan sebuah perusahaan kepada pasar di dunia maya. Ketiga hal di atas merupakan syarat mutlak yang harus dimiliki dan dikuasai pemakainnya untuk dapat berhasil menjalankan bisnis secara sukses.

\section{Innovation}

Aktivitas di internet adalah bisnis 24 jam, bukan 8 jam seperti layaknya perusahaan-perusahaan di dunia nyata. Keunggulan kompetitif (competitive advantage) sangat sulit dipertahankan mengingat apa yang dilakukan seseorang atau perusahaan internet lain sangat mudah untuk ditiru. Oleh karena itulah inovasi secara cepat dan terus-menerus dibutuhkan agar sebuah perusahaan dapat bertahan. Manajemen perusahaan harus mampu menemukan cara agar para pemain kunci di dalam organisasi (manajemen dan staf) dapat selalu berinovasi seperti layaknya perusahaan-perusahaan di Silicon Valley. Konsep learning organization patut untuk dipertimbangkan dan 
diimplementasikan di dalam perusahaan.

\section{Prosumption}

Di dalam ekonomi digital batasan antara konsumen dan produsen yang selama ini terlihat jelas menjadi kabur. Hampir semua konsumen teknologi informasi dapat dengan mudah menjadi produsen yang siap menawarkan produk dan jasanya kepada masyarakat dan komunitas bisnis. Contohnya adalah seseorang yang harus membayar Rp 5.000.000,- untuk mendapatkan atau sewa ruang data website (hosting) dengan besaran 10 Giga byte dan disubkontarakan/disewakan kembali dengan memecah besaran dari kapasitasnya, misalnya 1 gigabyte dapat disewakan atau dijual dengan harga satu juta rupiah. Dalam waktu singkat yang bersangkutan telah dapat memperoleh untung dari usaha kecil tersebut. Dalam konteks ini, individu yang bersangkutan dikategorikan sebagai prosumer.

\section{Immediacy}

Di dunia maya (internet), pelanggan dihadapkan pada beragam perusahaan yang menawarkan produk atau jasa yang sama. Dalam memilih perusahaan, mereka hanya menggunakan tiga kriteria utama. Secara prinsip mereka akan mengadakan transaksi dengan perusahaan yang menawarkan produk atau jasanya secara cheaper, better, dan faster dibandingkan dengan perusahaan sejenis. Mengingat bahwa switching cost di internet sangat mudah dan murah, maka pelanggan akan terus menerus mencari perusahaan yang paling memberikan benefit tertinggi baginya. Melihat hal inilah maka perusahaan harus selalu peka terhadap berbagai kebutuhan pelanggan yang membutuhkan kepuasan pelayanan tertentu.

\section{Globalization}

Esensi dari globalisasi adalah runtuhnya batas-batas ruang dan waktu (time and space). Pengetahuan atau knowledge sebagai sumber daya utama, tidak mengenal batasan geografis sehingga keberadaan entitas negara menjadi kurang relevan di dalam menjalankan konteks bisnis di dunia maya. Seorang 
Islamiconomic: Jurnal Ekonomi Keuangan dan Bisnis Islam Vol.7 No.1 Januari - Juni 2016

kapitalis murni akan cenderung untuk melakukan bisnisnya dari sebuah tempat yang murah dan nyaman, menjual produk dan jasanya kepada masyarakat yang kaya, dan hasil keuntungannya akan ditransfer dan disimpan di bank yang paling aman dan memberikan bunga terbesar. Segmentasi market yang selama ini sering dilakukan berdasarkan batas-batas waktu dan ruang pun harus didefnisikan kembali mengingat bahwa seluruh masyarakat telah menjadi satu di dalam dunia maya, baik komunitas produsen maupun konsumen.

\section{Discordance}

Ciri khas terakhir dalam ekonomi digital adalah terjadinya fenomena perubahan struktur sosial dan budaya sebagai dampak konsekuensi logis terjadinya perubahan sejumlah paradigma terkait dengan kehidupan seharihari. Semakin ringkasnya organisasi akan menyebabkan terjadinya pengangguran dimana-mana, mata pencaharian para mediator (brokers) menjadi hilang, para pekerja menjadi workoholic karena persaingan yang sangat ketat, pengaruh budaya barat sulit untuk dicegah karena dapat diakses bebas oleh siapa saja melalui internet, dan lain sebagainya merupakan contoh fenomena yang terjadi di era ekonomi digital. Ketidaksiapan sebuah organisasi dalam menghadapi segala kemungkinan dampak negatif yang timbul akan berakibat buruk (bumerang) bagi kelangsungan hidup perusahaan.

Digitalisasi ekonomi syariah mutlak dan harus untuk mengimbangi seiring perkembangan teknologi informasi dan komunikasi yang makin merambah dalam genggaman tangan (gadget), dan berbagai fitur aplikasi bisnis yang ditawarkan makin banyak dan mudah digunakan oleh user dan dunia usaha seperti industri, perbankan dan pendidikan, mau tidak mau suka tidak suka ekonomi tumbuh dan berkembang terutama ekonomi syariah yang sedang naik daun pada era sekarang ini. Produk dari pemegang peran ekonomi syariah seperti perbank-kan syariah dengan aplikasi mobile bankingnya, asuransi syari'ah dengan produk layananan onlinenya, maka digitilasasi ekonomi syari'ah 
Aan Anshori:Digitalisasi Ekonomi Syariah

terbentuk dengan sendirinya seiring ebutuhan dan teknologi pendukung yang sudah ada dan terus berkembang.

Digitalisasi merupakan istilah saja dalam merangkum database server yang dapat digunakan untuk transaksi online yang saling terhubung satu sama lain sehingga transaski dapat dilakuakan secara sistem otomatis menggunakan mesin, tinggal aplikasi dan alur prosesnya saja yang menggunakan metode islami dalam alur transaksi yang berasaskan pada kaidah ajaran islam dengan ketentuan yang sudah diatur dalam Al-qur'anul karim. Dengan demikian hanya alur dan prosesnya saja yang berbeda antara ekonomi konvensional dan ekonomi sayra'ah sedangkan peralatan dan mesinnya yang digunakan adalah sama.

\section{Kesimpulan}

Layanan komunikasi data yang saling terkoneksi satu dengan yang lainnya dan saling bertukar transaksi disegala informasi baik bisnis maupun non bisnis yang menghasilkan deal-deal yang saling menguntungkan berdasarkan kaidah islam, tidak ada yang merasa dirugikan baik secara moril dan materi sehingga terjadi kesinambungan interkoneksi bisnis yang mampu membangkitkan gairah ekonomi bernuansa islami. Terbentuknya data dan informasi yang tersimpan pada icloud ataupun server database yang mampu menampung jutaan transaksi bisnis dan non bisnis, kemudian data yang diperoleh dijadikan informasi yang dapat digunakan sebagai bahan awal untuk melakukan bisnis, dimana putaran transaksi bisnis yang dilakukan tersebut menjadikan digitalisasi ekonomi syariah, jika transaksi bisnis tersebut berlandasakan pada aturan islam maka hasilnya otomatis menjadi syar'i.

Hal yang mendasar dan melandasi digitalisasi ekonomi syari'ah hanya ada pada metode dan aturan main dari ajaran agama islam dalam melakukan transaksi yang syar'i menurut ajaran agama islam, karena semua urusan didunia sudah ada aturannya dalam kitab suci umat islam, metode tersebut dituangkan dalam algoritma dan dicoding dalam bahasa pemrograman yang dapat dipahami oleh mesin komputer sehingga otomasi mesin tersebut dapat melakukan digitalisasi perintah yang dilakukan oleh user dalam melakukan transaski bisnis dengan pemilik perusahaan, peralatan dari digititalisasi yang digunakan itu sama, yang berbeda hanyalah metodenya. 
Islamiconomic: Jurnal Ekonomi Keuangan dan Bisnis Islam

Vol.7 No.1 Januari - Juni 2016

\section{Pustaka Acuan}

Amir Machmud, 2010. BANK SYARIAH Teori, Kebijakan, dan Study Empiris di Indonesia. Erlangga

Ismail,2011. Perbankan Syariah. Kencana Prenada Media Group

Zachman, John A., 1999. A framework in information systems Architecture, New York: IBM Systems Journal .

Sujadi, edi purwo saputro. 2016 "e-banking: urgensi aspek trust di era e-service" .http://jurnal.upnyk.ac.id/index.php/semnasif/article/view/1229

http://suhanda666.wordpress.com/2011/05/25/e-banking/ akses. 10/10/2012

http://campuzherman.blogspot.co.id/2013/06/makalah-produkproduk-brisyariah.html

http://makalahegi.blogspot.co.id/2013/01/makalah-bank-syariah.html

\section{Catatan Akhir}

\footnotetext{
${ }^{1}$ http://www.hukumonline.com/berita/baca/lt576d43bf1f3ff/meraba-payung-hukum-untuk-trenekonomi-digital

${ }^{2}$ http://www.pengertianpakar.com/2015/01/pengertian-ruang-lingkup-manfaat-ekonomisyariah.html

${ }^{3}$ http://www.ilmuekonomi.net/2015/10/pengertian-dan-ciri-ciri-sistem-ekonomi-islam..html ${ }^{4} \mathrm{http}: / /$ www.ilmuekonomi.net/2015/10/pengertian-dan-ciri-ciri-sistem-ekonomi-islam..html ${ }^{5}$ http://muhamadilhamainulyaqin.ilearning.me/2014/07/08/modul-3-4-digital-economy-ekonomidigital-dan-retailing-in-electronic-commerce-e-tailing
} 
Aan Anshori:Digitalisasi Ekonomi Syariah

$\overline{-}$ 